\author{
Petra Pocrnić Perica \\ Vijeće sportske arbitraže pri Hrvatskom olimpijskom odboru \\ arbitar u CAS-u
}

\title{
UGOVOR O ARBITRAŽI U PRAVNIM STVARIMA VEZANIMA UZ MEĐUNARODNI SPORT
}

\author{
UDK: 341.6 796/799 \\ Primljeno: 15. 10. 2016. \\ Pregledni rad
}

\begin{abstract}
Ugovor o arbitraži temelj je svakog arbitražnog postupka pa tako i arbitražnog rješavanja sporova u pravnim stvarima vezanima uz sport. Kao i svaki drugi ugovor, i ugovor o arbitraži podliježe formalnim i materijalnopravnim pretpostavkama za valjanost. Specifičnost ugovora o arbitraži u sportu očituje se u posebnom načinu davanja pristanka na arbitražu pa će se odluka o valjanosti pristanka reflektirati na odluku o valjanosti samog ugovora. Arbitražni sud za sport (CAS) u Lausannei, često nazivan i Vrhovnim sudom za sport, institucija je za arbitražno rješavanje sporova u sportu koja svoju nadležnost crpi upravo iz takvog specifičnog ugovora o arbitraži. Iako je valjani ugovor o arbitraži uvjet za provođenje arbitražnog postupka, pa tako i postupka pred CAS-om, preispitivanje valjanosti javlja se i u fazi pravnog lijeka na arbitražni pravorijek, ali i još kasnije, u fazi priznanja i provedbe strane arbitražne odluke temeljem Njujorške konvencije o priznanju i izvršenju stranih arbitražnih odluka iz 1958. godine. Suvremeno doba svjedok je ljuljanja temelja sportske arbitraže kao sustava na svjetskom nivou. Slučaj Claudie Pechstein, koji je na globalnoj razini počeo pred CAS-om i nastavio se pred Švicarskim federalnim sudom, kulminaciju je doživio lokalno pred njemačkim sudovima. Sportska zajednica napeto je iščekivala odluku Njemačkog vrhovnog suda u lipnju 2016. godine kao što i dalje očekuje odluku Europskog suda za ljudska prava u Strasbourgu pred kojim je postupak još uvijek u tijeku. Članak analizira pozitivne propise i praksu sudova u odnosu na ugovor o arbitraži s kritičkim osvrtom usmjerenim na rezultat postupka pred sudovima u slučaju Claudie Pechstein.
\end{abstract}

Ključne riječi: arbitraža, sport, ugovor o arbitraži, CAS, Pechstein

\section{UVOD}

Rješavanje sporova u pravnim stvarima vezanima uz međunarodni sport povjerava se uglavnom arbitraži. Ovakav alternativan način rješavanja sporova $u$ odnosu na redovni sudski postupak karakteriziraju mnoge posebnosti, ali i unutar samih arbitražnih načina rješavanja sporova postoje posebnosti karakteristične za svaku industriju ili djelatnost iz koje je spor proizašao. Arbitraža u sportu tako nosi svoje specifičnosti, a jedna od značajnijih očituje se i u ugovoru o arbitraži kao 
temelju nadležnosti iz koje arbitražno vijeće ili arbitar pojedinac crpi ovlaštenje na postupanje u određenoj pravnoj stvari umjesto da se o toj pravnoj stvari odlučuje pred redovnim sudom. Da bi arbitražna odluka bila provediva, upravo taj temelj na kojem je arbitraža provedena mora biti čvrst. Kao i svaki drugi ugovor, ugovor o arbitraži, pa i onaj u pravnim stvarima vezanima uz sport, mora ispunjavati određene pretpostavke da bi bio valjan a da bi arbitraža posljedično za stranke proizvela željeni učinak, a to je da odluka bude konačna i provediva. U odnosu na sportsku arbitražu, upravo te pretpostavke obilježavaju određene posebne karakteristike, ali nose i probleme u praksi na koje nailaze sudovi kada preispituju njihovu postojanost. Iz provedenog istraživanja, koje je uključivalo metodu analize sudskih i arbitražnih odluka, znanstvenih radova i stručne literature, može se zaključiti da je kompleksnost problema rasla periodično i kronološki kako se razvijalo tržište i financijski ulozi o kojima se pred vijećima ili sudovima odlučivalo. Naime, iako se od osnutka Arbitražnog suda za sport u Lausannei (dalje: CAS) nije nailazilo na prepreke o priznanju odluke CAS-a pred nacionalnim sudovima, odnosno posredno priznanja ugovora o arbitraži sklopljenog na način kao i u brojnim slučajevima ranije, novije vrijeme svjedoči većim životnim ulozima sportaša o kojima ovisi i rezultat odlučivanja pa logično i većim naporima da se određeni pravni poslovi, dotad sklapani bez primjedbi, osporavaju kao ništavi. Najbolji primjer ovakvog razvitka prakse upravo je slučaj Cañas i onaj Claudie Pechstein, koji su uložili nekoliko godina borbe za zaštitu svojih prava i interesa, i u čijim slučajevima su se preispitivali ugovor o arbitraži i pretpostavke za valjanost, ali i druge glavne okosnice na kojima sustav sportske arbitraže postojano djeluje dugi niz godina. Za shvaćanje posebnosti problematike ugovora o arbitraži u sportu, može se zaključiti da prvenstveno valja naglasiti opća obilježja istog koja se mogu pronaći u bilo kojem drugom ugovoru i pretpostavkama za valjanost, ali i u praksi sudova koji su se s problemom valjanosti susreli.

\section{DEFINICIJA UGOVORA O ARBITRAŽI}

U literaturi i propisima nalaze se brojne definicije ugovora o arbitraži. Tako ga hrvatski Zakon o arbitraži (NN 88/01) u čl. 6 definira kao ugovor kojim stranke podvrgavaju arbitraži sve ili određene sporove koji su među njima nastali ili bi mogli nastati iz određenog pravnog odnosa, ugovornog ili izvanugovornog, a može se sklopiti u obliku arbitražne klauzule u nekom ugovoru ili u obliku posebnog ugovora. Bez obzira na točnu definiciju, sklapanjem ugovora o arbitraži stranke uvijek žele istu posljedicu, a to je da svoj spor povuku iz nadležnosti redovnih nacionalnih sudova i podvrgnu ga pred izabrani sud-arbitražu. Takav ugovor imati će željeni učinak, odnosno redovni sud će se proglasiti nenadležnim, ${ }^{1}$ samo ako je takav ugovor provediv. Da bi bio provediv, mora biti valjano sklopljen u formalnom i materijalnopravnom smislu te se mora odnositi upravo na spor koji je nastao. Slična

Ako se spor ne odnosi na isključivu nadležnost sudova. 
je regulativa i u drugim zemljama, posebno Švicarskoj, čije će zakonodavstvo biti vrlo važno u postupcima međunarodne sportske arbitraže.

\section{FORMALNA VALJANOST UGOVORA O ARBITRAŽI}

Formalna valjanost ugovora o arbitraži vezana je uz pitanje jesu li stranke uistinu pristale na arbitražu. Posljedično tome, pitanje forme ugovora o arbitraži i pitanje davanja pristanka često su isprepletena (Lew, Mistelis, Kroell, 2003.). Iako većina propisa predviđa da ugovor o arbitraži bude sklopljen u pisanom obliku ili barem pismeno evidentiran, ${ }^{2}$ postoje i iznimke ${ }^{3} \mathrm{u}$ razmišljanjima koje priznaju valjanim ugovor o arbitraži iako je zaključen usmeno. ${ }^{4}$ Iako je ratio iza zahtjeva pisanog oblika zapravo razlog što se stranke ugovorom o arbitraži odriču svojih ustavnih prava na pristup redovnom sudu, ali i to što je iz pisanog ugovora lakše utvrditi pravu volju stranaka (jer u pisanom obliku sadržava sporazum stranaka), u teoriji se često ta pretpostavka valjanosti kritizira, te se ističe kao besmislenom činjenicu da je dozvoljeno sklopiti ugovor višemilijunske vrijednosti u usmenom obliku dok će ugovor o arbitraži biti ništav samo zbog nedostatka forme (makar je prava volja stranaka bila drugačija). Slijedom navedenoga, smatra se (Lew, Mistelis, Kroell, 2003.), nema opravdanja podvrgavati ugovor o arbitraži strožim pravilima od onih koja vrijede za sve ostale ugovore kada propisivanje obvezatnog pisanog oblika ne jamči ujedno i pravnu sigurnost stranaka.

Pitanja i problematika formalne valjanosti ugovora o arbitraži općenito, zrcalno se preslikavaju i na ugovor o arbitraži u pravnim stvarima vezanima uz sport, što znači da će i sudovi odnosno arbitražna vijeća biti suočeni s istim upitnicima u svom radu kao i izazovu analize i pronalaženju odgovora jesu li ispunjeni uvjeti koji daju ovlaštenje na postupanje arbitražnom vijeću ili arbitru pojedincu. Sukladno teoriji Kompetenz-Kompetenz, arbitražno vijeće ima pravo odlučivati o svojoj nadležnosti, odnosno preispitivati postoji li u formalnom i materijalnopravnom smislu valjani ugovor o arbitraži na kojemu će se temeljiti njegova nadležnost na postupanje i odlučivanje o biti stvari. Ovisno o tome o kojem arbitražnom tijelu se radi, ovisit će i pitanje koja pravila se primjenjuju. U postupcima pred CAS-om primjenjivat će se Pravilnik o postupku CAS-a te supsidijarno švicarsko pravo kao mjesto sjedišta arbitraže.

2 Originalni tekst na engleskom jeziku: „evidenced in writting“, čl. 7 (2) Model zakona.

Arbitration Act 1996 u čl. 6 st. 2 priznaje neke kategorije kvaziusmenog ugovora.

4 Kao što je to francusko pravo kada je u pitanju arbitraža s međunarodnim obilježjem, odluka francuskog suda Cour d'appel Paris, 8 June 1995, Sarl Centro Stoccagio Grani v SA Granit u: Lew, D. M. Julian; Mistelis, Loukas A.; Kroell, Stefan M., Comparative International Commercial Arbitration, Nizozemska, 2003., str. 130. kaazi do preispitivanja valjansomo dkojih svaki način nosi svoju problematiku. podredno švicarsko pravo kao mjesto sjedišta arbit 
Članak R27 Pravilnika o postupku pred CAS-om ${ }^{5}$ (dalje: Pravilnik CAS-a) propisuje da se Pravilnik primjenjuje u svakom onom slučaju u kojem su stranke ugovorile nadležnost CAS-a. Takav ugovor može proizlaziti iz arbitražne klauzule sadržane u ugovoru ili propisima, odnosno naknadnom ugovoru o arbitraži (redovni postupak) ili pak može uključivati žalbu podnesenu na odluku saveza, udruge ili tijela vezanog uz sport gdje statut ili unutarnja pravila takvog tijela propisuju mogućnost podnošenja žalbe CAS-u (žalbeni postupak). Članak R28 Pravilnika CAS-a propisuje da je sjedište arbitraže u Lausannei, Švicarska.

Kako Pravilnikom CAS-a nisu propisane daljnje odredbe koje se odnose na formu ugovora o arbitraži, primjenjuju se odredbe švicarskog zakona o međunarodnom privatnom pravu $^{6}$ (dalje: PILA), kao zakon mjesta gdje je sjedište arbitraže. Ovo proizlazi iz čl. 176 PILA-e koji propisuje da će se PILA primjenjivati u svakom onom slučaju u kojem je sjedište arbitraže u Švicarskoj ako u trenutku sklapanja ugovora o arbitraži barem jedna od stranaka nema sjedište odnosno prebivalište u Śvicarskoj. U odnosu na formu ugovora o arbitraži, čl. 178 st. 1 PILA-e propisuje da je arbitražni ugovor valjan ako je sklopljen u pismenoj formi putem telefaksa, teleksa, telekopirke ili drugih sredstava komunikacije koji tekstom potvrđuju uvjete sklopljene ugovorom (slobodan prijevod). Ako se tekst PILA-e usporedi s čl. II. Konvencije o priznanju i ovrsi stranih arbitražnih odluka iz 1958. (dalje: Njujorška konvencija) ${ }^{7}$ vidljivo je da je PILA predvidjela brojnije oblike mogućnosti komunikacije među strankama od konvencije. Uzimajući u obzir činjenicu da PILA ne propisuje detaljnije definiciju ugovora o arbitraži ili njegove bitne sastojke, može se zaključiti o liberalnijem pristupu prema pitanju postojanja pisanog sporazuma, s obzirom na to da zadnje riječi čl. 178 st. 1 PILA-e upućuju na to da će se kao pisani oblik priznati svaki zapis koji potvrđuje uvjete sporazuma. Također, ugovor ne mora biti potpisan već je bitno da je sporazum izražen pismeno, što zapravo znači da sadržava bilo kakvu pisanu izjavu volje stranaka.

U postupcima pred CAS-om više puta su preispitivani razlozi za postojanje formalne valjanosti ugovora o arbitraži. U predmetu WADA v Judo Bond Nederland et $a l^{8}$ utvrđeno je da će se, s obzirom na švicarski liberalan pristup zahtjevu pisane forme ugovora o arbitraži, bilo kakva izjava volje na sklapanje ugovora o arbitraži izražena u pismenoj formi smatrati zadovoljenjem pretpostavki formalne valjanosti. Navedeno je potvrđeno i odlukom Švicarskog federalnog suda ${ }^{9} \mathrm{u}$ kojoj isti utvrđuje kako je dovoljno da arbitražno vijeće utvrdi da je stranka (u tom slučaju nogometni

5 Code of Sports-related Arbitration and Mediation Rules, Court of Arbitration for Sport, www.tascas.org, zadnje posjećeno 30. IV. 2016.

${ }_{6}$ Swiss private International Law Act ili skraćeno PILA dostupno na https://www.swissarbitration. org.

7 New York Convention 1958, dostupno na http://www.uncitral.org/pdf/english/texts/arbitration/ NY-conv/New-York-Convention-E.pdf.

8 CAS 2012/A/2747 od 15. IV. 2013., WADA v. Judo Bond Nederland, Dennis de Goede \& Dopingautoriteit, dostupno na www.tas-cas.org.

9 ATF 4A_640/2010 od 18. travnja 2010., A. v. WADA, FIFA \& CFA, para 3.3.3., dostupno na http:// www.swissarbitrationdecisions.com. 
trener) registrirana kod nacionalnog nogometnog saveza te je u takvom svojstvu obvezna na poštovanje statuta i pravila Svjetske nogometne federacije (dalje: FIFA, posredno preko članstva nacionalnog saveza u FIFA-i) uključujući i pravila za borbu protiv dopinga nacionalnog saveza, te da nije potrebno dalje utvrđivati detalje takve registracije, ukoliko stranke nisu osporile formalnu registraciju već su osporavale činjenicu da je upućivanjem na arbitražnu klauzulu sadržanu u pravilima FIFA-e ustanovljena nadležnost CAS-a.

Daljnje važno pitanje koje se postavilo u praksi jest da li je zadovoljen zahtjev za sklapanjem ugovora o arbitraži u pisanoj formi i u slučaju kada pisana komunikacija općenito upućuje na opće uvjete ${ }^{10}$ ili je potrebno posebno u uputi spomenuti i arbitražnu klauzulu sadržanu u tim općim uvjetima. Stav Švicarskog federalnog suda prilikom primjene čl. II. Njujorške konvencije jest da čl. II. mora biti interpretiran u skladu sa svojom svrhom i interesom koji taj članak štiti, a to je da je zahtjev za pisanom formom namijenjen zaštiti stranaka koje zaključuju ugovor koji ujedno znači i odricanje od određenih prava, posebno onoga na pristup redovnom sudu. Što se tiče određenog interesa koji se preispituje, najvažnije je da se preispitaju sve važne okolnosti pojedinog slučaja, posebno jesu li stranke iskusne u svojem poslu ili nisu, jer se zahtijeva različit pristup sklapanju ugovora koji se odnosi na opće uvjete ako su takvi uvjeti već strankama poznati ili oni to nisu. ${ }^{11}$ Navedeno pitanje postavilo se i u postupcima pred CAS-om. U svojoj odluci broj CAS 2000/A/262 od 28. srpnja 2000. (Reeb, 1998.) CAS je utvrdio da švicarsko pravo zahtijeva valjanost ugovora o arbitraži, tj. da bude sklopljen u pismenom obliku. Svrha pismene forme prvenstveno da je upozori stranke na postojanje arbitražne klauzule, a drugo da služi kao dokaz. Kada postoji uputa (referenca) na drugi dokument, a posebno ako je takva uputa opće prirode tj. ne spominje izričito arbitražnu klauzulu, odgovor na pitanje jesu li ispunjeni uvjeti za formalnu valjanost ugovora o arbitraži ovisi o specifičnosti svakog slučaja. Opća uputa nije dovoljna kada stranka, koja daje ponudu na sklapanje ugovora o arbitraži, zna ili je iz iskustva morala znati da druga stranka nije na takvu klauzulu željela pristati ili je takva klauzula (arbitražna) neuobičajena u navedenim okolnostima. S druge strane, opća je uputa (global reference, slobodan prijevod) dovoljna i valjana između stranaka koje su iskusne u određenom području poslovanja ili kada je arbitražna klauzula uobičajen dio poslovanja u određenom poslovnom sektoru, bez obzira na to je li druga strana zaista pročitala dokument na koji se upućuje i time znala da je u istom sadržana takva klauzula. U spornom slučaju, stranka profesionalni košarkaš, prema mišljenju CAS-a, smatra se iskusnom u području profesionalnog sporta, a arbitražne klauzule uobičajeni su dio pravila sportskih federacija i saveza ili procesna pravila takvih tijela upućuju na CAS kao nadležno tijelo za žalbe uz izričito odricanje prava na podnošenje istih redovnom sudu. Takav princip dobre vjere potvrđen je i od strane Švicarskog federalnog suda (Reeb,

\footnotetext{
10 Eng: ,general reference“.

11 Swiss Tribunal Federal, Tradax Export SA (Panama) v Amoco Iranian Oil Company, od 7. veljače 1984., para 10, dostupno na http://www.bger.ch/fr.
} 
1998.). Naime, pred Švicarskim federalnim sudom pojavio se slučaj profesionalnog jahača koji je potpisao standardni obrazac ugovora s Međunarodnom federacijom u konjičkom sportu (dalje: FEI) a koji je upućivao na poštovanje pravila te federacije ali nije izričito sadržavao arbitražnu klauzulu. Sporno pitanje je bilo zadovoljava li arbitražni ugovor sklopljen putem upute uvjete propisane čl. 178 PILA-e. Sud je zaključio da je pitanje formalne valjanosti zapravo pitanje postojanja zamjene sudovanja pred redovnim sudom onim putem arbitraže, a sve temeljem postojanja ugovora sklopljenog u valjanoj formi, dok efekt isključivanja nadležnosti ovisi zapravo o valjanosti takvog ugovora o isključivanju. U konkretnom slučaju, sportaš je znao za postojanje arbitražne klauzule u trenutku potpisa ugovora koji je na klauzulu upućivao i na istu nije izjavio nikakav prigovor. Takvo ponašanje sportaša ne može proizvesti kod onoga koji je predložio sklapanje ugovora nikakav drugi zaključak nego da je upravo to želja sportaša. Kako je i do postupka pred Švicarskim federalnim sudom došlo žalbom sportaša na odluku CAS-a (koji je postupao upravo po prijedlogu tog istog sportaša koji se žalio na odluku matične federacije, dakle temeljem arbitražne klauzule valjanost koje se osporava), sud je ovo smatrao samo dodatnim argumentom o valjanosti takve klauzule. ${ }^{12}$

\section{MATERIJALNOPRAVNA VALJANOST UGOVORA O ARBITRAŽI}

Samu srž arbitraže kao načina rješavanja sporova čini arbitražni ugovor kao izraz volje stranaka da svoj sadašnji ili budući spor riješe putem arbitraže umjesto pred redovnim sudom, a to je pravo koje im pripada temeljem ustava i zakona. Kao i svaki drugi ugovor, ugovor o arbitraži sklapa se prihvatom ponude. Da bi ugovor bio valjan u materijalnopravnom smislu, on mora biti rezultat istinske volje stranaka koja nije ugrožena vanjskim čimbenicima. Ovo se posebno odnosi na pristanak na arbitražu koji označava prihvat ponude na sklapanje arbitražnog ugovora. Dakle, ako nema pristanka, nema niti prihvata, pa posljedično tome nema niti sklapanja ugovora. Iako zvuči jednostavno, u praksi nije uvijek lako utvrditi je li i kako pristanak iskazan. Ako je arbitražna klauzula sadržana u dokumentu koji je rezultat pregovora, a ujedno je potpisan od svih stranaka u postupku, sud ili vijeće koje se suoči s takvim pitanjem neće imati previše problema u odlučivanju. Međutim, u praksi se javljaju slučajevi ugovora koji kao sastavni dio sadržavaju uputu na opće uvjete, a ovi pak sadržavaju arbitražnu klauzulu. Kako arbitražna klauzula u takvom slučaju nije sastavni dio pisanog teksta ugovora, može se dogoditi da stranka na takvu klauzulu ne obraća previše pozornosti, pa u trenutku nastanka spora stranka ospori valjanost arbitražnog ugovora u pogledu forme (o čemu je bilo riječi), ali i u pogledu materijalnopravnih pretpostavki, ističući da na arbitražu zapravo nikada nije pristala.

12 Izvadak odluke Švicarskog federalnog suda u predmetu N v FEI od 31. X. 1996. u Reeb, M., 1998. 
Materijalnopravna valjanost ugovora o arbitraži posebno je važno pitanje kada se utvrđuje postojanje ugovora o arbitraži u pravnim stvarima vezanima uz sport. Kao spornim, u praksi se najčešće postavilo pitanje valjanosti pristanka na arbitražu, odnosno pitanje je li uopće ugovor o arbitraži sklopljen, pa posljedično tome i obvezuje li on stranku koja pitanje pristanka osporava. U sporovima vezanima uz sport u praksi je pristanak na arbitražu moguće iskazati u nekoliko različitih slučajeva specifičnih upravo za sport, sportske propise i sportska natjecanja, od kojih svaki način nosi svoje probleme. Ovo je zapravo odraz specifičnosti sportske industrije, brzine njezina djelovanja, ali i hijerarhijskog sustava u koji je uklopljen. Osnovni uvjet da se spor u sportu riješi putem arbitraže jest postojanje ugovora o arbitraži, što uključuje ponudu za sklapanje ugovora o arbitraži i prihvat te ponude. ${ }^{13}$

U sportskoj industriji uobičajeno je da interni propisi udruga-klubova, nacionalnih saveza i međunarodnih federacija, sadržavaju odredbu koja propisuje da će se sporovi rješavati putem arbitraže (dakle jednostranu ponudu), a sportaš potpisom kojim prihvaća članstvo u udruzi ili potpisom kojim potvrđuje sudjelovanje na sportskom događaju u organizaciji te udruge iskazuje svoj pristanak odnosno prihvat ponude. Ako sportaš ne želi biti vezan takvom jednostranom ponudom na koju je pristajanjem na članstvo dao prešutni pristanak, istom mora prigovoriti jer će u suprotnom biti vezan ugovorom o arbitraži na sličan način kao da se, nakon pokretanja arbitražnog postupka, upustio u raspravljanje bez isticanja prigovora nenadležnosti. Niti ovakvo pravilo nije bez iznimke, odnosno potrebno je razmotriti sve okolnosti pojedinog slučaja, stoga neće npr. postojati ponuda za sklapanje ugovora o arbitraži ako je ista izvučena iz općih informacija objavljenima na web-stranici. ${ }^{14}$

U praksi su česti slučajevi i kada pristupnica na natjecanje (originalni međunarodni naziv: «Player Entry Form») sadržava arbitražnu klauzulu. U takvim slučajevima, ako dođe do spora, u preispitivanju valjanosti ugovora o arbitraži, bit će važan točan sadržaj klauzule i pristupnice, ali i to kakva je dosadašnja praksa među strankama. Pa će u slučaju (kakav se pojavio pred Švicarskim federalnim sudom) u kojem se organizator natjecanja poziva na postojanje ugovora o arbitraži za svaki spor sa sportašem biti utvrđeno nepostojanje ugovora o arbitraži ako se arbitražna klauzula u pristupnici na natjecanje odnosila samo na to specifično natjecanje. ${ }^{15}$

Dok arbitražna klauzula u unutarnjim propisima sportskih udruga predstavlja ponudu na sklapanje ugovora o arbitraži, pristupanjem odnosno potpisom zahtjeva za pristup članstvu, takva ponuda je prihvaćena i ugovor o arbitraži je sklopljen. Kako je obveza udruga da donose unutarnje propise koji reguliraju djelatnost udruge, takvi propisi, pa i arbitražna klauzula koja je u njima sadržana, po prirodi stvari uvijek su u pisanoj formi, kao što je u pisanoj formi i pristupnica za članstvo odnosno pristupnica za sudjelovanje na određenom natjecanju kojom se traži sudjelovanje

13 CAS 2009/A/1910 odluka o nadležnosti od 09. IX. 2010., dostupno na www.tas-cas.org.

14 Slučaj Hrvatskog golf saveza protiv Hrvatskog olimpijskog odbora, odluka CAS 2012/A/2813 od 23. I. 2013., www.tas-cas.org.

15 Odluka Švicarskog federalnog suda broj 4A_358/2009 od 06. XI. 2009. kojom se poništava odluka CAS-a broj CAS 2008/A/1564, WADA v F.B.\&IIHF od 23. VI. 2009. u: Mavromati i Reeb, 2015. 
ali ujedno prihvaća i obveza na poštovanje pravila i propisa organizatora natjecanja. Ovo je bitno stoga što, iako u praksi postoje slučajevi prigovora ništavosti ugovora o arbitraži, možda čak usmjereni i na formalnu ništavost, temeljno se zapravo radi o prigovoru materijalnopravne ništavosti jer detaljnijom analizom tih prigovora utvrđuje se da su oni zapravo usmjereni na nedostatak ili kvalitetu pristanka u sklapanju tog ugovora, a ne na činjenicu da ne postoji propisana forma za izjavljivanje tog pristanka.

Člankom R27 Pravilnika CAS-a propisano je da se Pravilnik primjenjuje svaki onaj put kada su stranke ugovorile nadležnost CAS-a, dok se isti ugovor može izvesti iz arbitražne klauzule sadržane u ugovoru, pravilima, ugovoru o arbitraži sklopljenom nakon nastanka spora ili pak uputom o pravnom lijeku sadržanom u statutu ili posebnom ugovoru. Osim što propisuje nadležnost CAS-a, ovaj članak značajan je jer na jednom mjestu kodificira praksu odnosno opisuje na koji je način sve moguće sklopiti ugovor o arbitraži u pravnim stvarima vezanima uz sport. Pravilnik, kao i u slučaju formalne valjanosti, ne propisuje pobliže uvjete za materijalnopravnu valjanost ugovora o arbitraži, pa će se u postupcima pred CAS-om na isto pitanje primjenjivati švicarsko pravo, odnosno švicarska PILA. PILA u čl. 178 propisuje da je ugovor o arbitraži materijalnopravno valjan ako je alternativno ispunjen neki od sljedećih uvjeta: ako je valjan prema pravu koje su stranke odabrale kao mjerodavno pravo za predmet spora, ili posebno prema pravu koje je mjerodavno za glavni ugovor ili ako je valjan prema švicarskom pravu. Sukladno navedenom primarnom kriteriju stranačke autonomije u izboru mjerodavnog prava za ugovor o arbitraži, stranke mogu izabrati jedno pravo kao mjerodavno za glavni ugovor, a drugo kao mjerodavno za ugovor o arbitraži. Dakle jednako kao i Njujorška konvencija, i švicarska PILA podupire stranačku autonomiju u izboru mjerodavnog prava za ugovor o arbitraži, a u odsustvu istoga, podvrgava ga pravu sjedišta arbitraže. Osim citiranog članka 178 st. 2 PILA-e, isti zakon ne propisuje daljnje uvjete vezane za materijalnopravnu valjanost ugovora o arbitraži, pa bismo u traženju odgovora na neko konkretnije pitanje trebali posegnuti za propisima švicarskog obveznog prava.

U sporovima vezanima uz sport koji se vode pred CAS-om, sud ce interpretirati ugovor o arbitraži kao što bi interpretirao bilo kakav drugi trgovački ugovor (Mavromati i Reeb, 2015.), pa će u tom smislu prvenstveno posegnuti za interpretacijom prave volje stranaka izražene u određenom dokumentu. Kada je volja odnosno namjera stranaka jasna da određeni spor podvrgnu arbitraži, i CAS će dati snagu takvoj volji, priznajući valjanim ugovor o arbitraži, iako je možda ugovor iz neke perspektive nejasan, nepotpun, nedosljedan ili mu određeni elementi nedostaju. Ovo sve dok takav ugovor nije na štetu prava neke od stranaka.

Švicarski federalni sud povodom preispitivanja odluke CAS-a ${ }^{16}$ odnosno preispitivanja valjanosti ugovora o arbitraži, u jednoj svojoj odluci, ${ }^{17}$ interpretirao je ugovor o arbitraži i istaknuo da takva interpretacija slijedi načela koja se inače

16 CAS 2003/O/502 od 29. X. 2003., dostupno na www.tas-cas.org.

17 ATF 4P.253/2003 od 25. III. 2004., dostupno na http://www.bger.ch/fr. 
primjenjuju kada se interpretiraju privatne izjave volje (,private interpretation of will"). Dakle, pravi sporazum stranaka bit će uvijek u fokusu i njemu se daje najveći značaj. Ako se takav sporazum ne može utvrditi subjektivno, primjenjuje se objektivni kriterij, tražeći odgovor na pitanje na koji način bi svatko, u skladu s načelom dobre vjere, takav sporazum razumio. ${ }^{18}$

Slijedom navedenoga, slučaj potpisivanja obrasca ugovora od strane sportaša koji sadrži obvezu poštovanja propisa matične federacije koji sadržavaju arbitražnu klauzulu, ali navedeni obrazac ne sadrži arbitražnu klauzulu, interpretirat će se i valjanost prosuđivanja u skladu s konkretnim okolnostima slučaja i načelom dobre vjere.

U teoriji i praksi može se uvidjeti razlika (Rigozzi i Robert-Tissot, 2015.) u stajalištima u slučaju obrazlaganja prirode sportske arbitraže i pristanka na istu. Dok jedni priznaju nekonsenzualnu prirodu sportske arbitraže (dakle da zapravo pristanka nema) uz istovremeno davanje razloga za ozakonjenje valjanosti odricanja na pravo pristupa redovnom sudu, kao što je to slučaj švicarskih sudova, drugi su mišljenja da je i takvo davanje pristanka, iako prisilno, ipak valjani način davanja pristanka. Ovo drugo stajalište zauzeo je engleski sud u slučaju Stretford, ${ }^{19}$ Paula Stretforda, tada službenog agenta poznatog engleskog nogometaša Waynea Rooneya. Spor je proizašao iz licence agenta na zastupanje sportaša koja je sadržavala arbitražnu klauzulu. Nogometni savez Engleske pokrenuo je postupak protiv Stretforda koji je, pak, pokrenuo postupak pred redovnim sudom u kojem je tražio preispitivanje zakonitosti disciplinskog postupka. Nogometni savez zatražio je prekid postupka pred redovnim sudom temeljem čl. 9. engleskog zakona o arbitraži iz 1996. (Arbitration Act 1996), što je Stretford osporavao, smatrajući da je arbitražna klauzula ništava jer da je protivna odredbama čl. 6. Europske konvencije za zaštitu ljudskih prava i temeljnih sloboda (dalje: ECHR). Ovakav prigovor Stretford je obrazlagao time da zapravo nije imao izbora nego pristati na arbitražnu klauzulu ako se želio nastaviti baviti djelatnošću sportskog agenta. Iako je sud priznao da je Stretford zapravo morao potpisati ugovor o arbitraži, ipak takvo uvjetovanje za bavljenjem djelatnošću, smatrao je sud, ne može se izjednačiti s prisilom, stoga je ugovor o arbitraži i pristanak utvrdio valjanim. Nije našao niti da bi isto bilo propisno javnom poretku, već upravo suprotno, da je arbitraža, kao postupak, u javnom interesu, odnosno potvrda valjanosti ugovora o arbitraži sklopljenog na ovakav način upravo je provođenje javnog interesa koji je u pozadini zakona o arbitraži iz 1996.

18 ATF 4P.162/2003 od 21. XI. 2003., dostupno na http://www.bger.ch/fr.

19 Stretford v. Football Association Ltd, High Court (Chancery) (EWHC (CH) 479 (2006.), objavljeno u I.S.L.R.SLR39-48, 46-47, paras 42,45,48, 2006. 


\subsection{Slučaj Hrvatskog golf saveza}

Pred CAS-om se pojavio zanimljiv slučaj utvrđivanja prave volje stranaka odnosno pitanja je li sklopljen ugovor o arbitraži u slučaju u kojem je Hrvatski golf savez podnio žalbu za odluku Vijeća sportske arbitraže. ${ }^{20}$ Vijeće sportske arbitraže (dalje: VSA) nezavisno je tijelo koje djeluje pri Hrvatskom olimpijskom odboru (dalje: HOO), a temeljem čl. 52 Zakona o sportu (NN, 150/08, 124/10, 124/11, 86/12, 94/13,85/15, 19/16) donosi odluke povodom zahtjeva za izvanredno preispitivanje odluka sportskih udruga protiv kojih su iscrpljena ili ne postoje sredstva druge pravne zaštite. Nad Hrvatskim golf savezom otvoren je stečaj pa ga je s te osnove odlukom Skupštine HOO-a isključio iz članstva. Hrvatski golf savez je zakonitost odluke o prestanku članstva pokušao osporiti pred VSA, zahtjevom za izvanredno preispitivanje odluke skupštine Hrvatskog olimpijskog odbora. VSA je zahtjev za izvanrednim preispitivanjem odbacilo, ${ }^{21} \mathrm{~s}$ obzirom na to da isti nije bio podnesen u propisanom roku. Protiv takve odluke Hrvatski golf savez podnio je žalbu CAS-u, temeljeći nadležnost CAS-a na tekstu objavljenom na službenoj webstranici HOO-a na kojoj je, osim opisa djelatnosti Sportskog arbitražnog sudišta i VSA (pravila postupka koji uređuje strukturu, nadležnost i sastav), između ostalog pisalo i da se kao pravni lijek na odluku VSA-e može podnijeti žalba CAS-u. Žalitelj je navedenu objavu smatrao ponudom na sklapanje ugovora o arbitraži u kojoj je nedvojbeno iskazan pristanak HOO-a da bude vezan ugovorom o arbitraži u slučaju prihvata takve ponude, čemu je HOO prigovorio. CAS je prilikom utvrđivanja postojanja svoje nadležnosti prvenstveno počeo s analizom teksta objavljenim na službenoj stranici HOO-a ne bi li došao do odgovora na pitanje proizlazi li iz istog namjera vezanosti ugovorom o arbitraži te bi li takva objava na web-stranici mogla biti shvaćena od treće strane koja postupa u dobroj vjeri kao izjava volje HOO-a da prema toj trećoj strani bude vezan ugovorom o arbitraži koji bi posljedično bio temelj za pokretanje arbitražnog postupka. Interpretirajući tekst, CAS se vodio prvenstveno načelom međusobnog povjerenja među strankama, posebno stoga što je Švicarski federalni sud već utvrdio da ugovor o arbitraži, da bi bio valjan, mora ispunjavati uvjete za materijalnopravnu valjanost propisane čl. 178 st. 2 PILA-e. Pristanak na arbitražu mora biti utvrđen, a ugovor o arbitraži interpretirat će se u skladu s općim načelima prava, posebice načelom dobre vjere. Uzimajući navedeno u obzir, CAS je zaključio da elementi web-publikacije, bez obzira na to što je publikacija na webu javna i za uvid nije potrebna lozinka već joj svatko može pristupiti, imaju za svrhu upoznavanje javnosti o općim informacijama vezanima za djelovanje VSA-e odnosno da je objavljeni tekst zapravo sažetak opće ideje o postupku arbitraže, dok je za detaljnije podatke o nadležnosti, sastavu i pravilima postupka potrebno obaviti uvid u službena pravila. Iz navedenoga proizlazi da je namjera HOO-a, kada je na službenoj stranici objavio sporan sadržaj, bila samo upoznavanje javnosti o općim informacijama, te se takvu objavu ne može kvalificirati kao namjeru stranke da bude vezana arbitražnom klauzulom koja bi se odnosila na sve odluke VSA-e. Također,

20 CAS 2012/A/2813 od 23. I. 2013., dostupno na www.tas-cas.org.

21 Zaključak broj 13/11-VSA od 13. IV. 2012. (neobjavljeno). 
takva objavljena informacija je i nepotpuna, jer joj nedostaju bitni elementi ponude, konkretnije na što se ponuda točno odnosi, a žalitelj nije dostavio nikakav dokaz na okolnost međusobne komunikacije koja bi potvrdila namjeru HOO-a da bude vezan arbitražnom klauzulom u bilo kojem drugom slučaju osim onih koji se odnose na Olimpijske igre (kako proizlazi iz statuta HOO-a). Posebno, objava ne može niti biti shvaćena drugačije od strane žalitelja ako on postupa u dobroj vjeri, jer je isti bivši član HOO-a i kao takav je sudjelovao u radu skupštine i glasao kada se pravilnik o postupku pred VSA-om koji ne sadrži arbitražnu klauzulu donosio, te mu time mora biti jasno da se u slučaju pozivanja na postojanje ugovora o arbitraži ne može pozivati samo na jednu objavu na web-stranicama. Slijedom navedenoga, zaključeno je da se objava ne može smatrati ponudom za sklapanje ugovora o arbitraži koji bi se odnosio na žalbu na jednu ili više odluka, već će se u obzir uzimati mjerodavna pravila koja točno propisuju kada je CAS nadležan i u odnosu na koje odluke. Kako je utvrđeno nepostojanje valjane ponude, ne može biti niti valjanog prihvata ponude, pa posljedično niti ugovora o arbitraži kao temelja nadležnosti CAS-a.

\subsection{Slučaj Guillermo Cañas v. ATP}

Slijedom do sada navedenoga, razvidno je da opća načela ugovornog prava propisuju slobodnu volju kao bitan sastojak ugovora odnosno nedostatak iste kao razlog za ništavost. U biti svakog ugovora jest konsenzus stranaka izjavljen na način i u formi propisanoj kao pretpostavka valjanosti posljedice takvog konsenzusa - ugovora. Je li i ugovor o arbitraži u stvarima vezanima za sport jednako tako konsenzualne prirode, upitno je. Međutim za razumijevanje davanja pristanka za rješavanje sporova arbitražom, važno je razumjeti kontekst sklapanja arbitražnog ugovora u sportu, stranke takvog ugovora te njihov odnos.

Ovo najbolje ilustrira slučaj ${ }^{22}$ koji se pojavio pred CAS-om, a poslije i pred Švicarskim federalnim sudom, u kojem su se sudovi na opsežan način bavili upravom tom temom - pristankom i njegovom posljedicom. Guillermo Cañas profesionalni je tenisač rođen 1977. godine, s prebivalištem u Buenos Airesu, Argentina. ATP Tour ili, punim nazivom, «The Association of Tennis Professionals Tour» (dalje u tekstu: ATP) neprofitna je organizacija sa sjedištem u Delawareu (SAD), čiji su članovi profesionalni tenisači i organizatori turnira, uključujući i Cañasa koji je bio član ATP-a od 1995. godine, a od 2005. godine bio je član tijela pod nazivom Vijeće sportaša. ATP izdaje pravila (na koja se izričito primjenjuje pravo države Delaware), obvezna za članove, a ista se posebice odnose na borbu protiv dopinga. Pravila propisuju i sankcije za njihovo kršenje koje izriče ATP Antidoping tribunal na čije odluke stranka ima pravo žalbe CAS-u. Sukladno čl. P.3. Pravila ATP-a iz 2005. godine, odluka CAS-a stupa na snagu odmah i sve stranke se obvezuju istu

22 Švicarski federalni sud, odluka 4P-172/2006 od 22. III. 2007. (ATF 133 III 235, 243), Guillermo Cañas v. ATP Tour \& CAS, u Geisinger, Elliott; Trabaldo de-Mestral, Elena, Sports Arbitration: A Coach for Other Players?, Association Suisse de 1'Arbitrage, ASA Special Series No.41, 2015., str. 263-298. 
odmah provesti. Dana 21. veljače 2005., dok je sudjelovao na turniru u Meksiku, Cañas je podvrgnut doping kontroli na način da je dao uzorak urina te je analizom i A i B uzorka utvrđeno da se u sportaševu tijelu nalazi diuretik koji je ujedno na popisu zabranjenih supstanci Svjetske antidoping agencije (dalje: WADA). Cañas je proglašen krivim za kršenje antidoping pravila uz sankciju izricanja razdoblja nepodobnosti u razdoblju od dvije godine, uz oduzimanje svih nagrada dobivenih na predmetnom turniru. Cañas se na odluku žalio CAS-u s argumentom da za uzimanje zabranjene supstance nije kriv, podredno da je kažnjavanje za ponašanje bez krivnje suprotno pravu države Delaware kao i europskim i američkim pravilima o tržišnom natjecanjima. Povodom žalbe, CAS je donio odluku (23. V. 2006.) u kojoj utvrđuje da je igrač uspio dokazati činjenicu da je zabranjena supstanca u igračevo tijelo ušla slučajno. Naime, igrač se razbolio od gripe, tražio je od doktora lijek, propisan mu je liječnički recept, međutim osoba zaposlena u organizaciji turnira je iz ljekarne igraču donijela lijek koji je bio namijenjen drugoj osobi (treneru jednog drugog igrača). Bez obzira na navedeno, Cañas kao iskusni igrač i član Vijeća igrača pri ATP-u, a uzimajući u obzir da je lijek prošao kroz nekoliko ruku, trebao je lijek iscrpno provjeriti i osigurati da ne sadrži zabranjene supstance. Slijedom navedenoga, CAS je žalbu djelomično usvojio, smanjivši razdoblje nepodobnosti na petnaest mjeseci, te naredio ATP-u da Cañasu vrati nagrade koje je osvojio nakon turnira.

Na ovakvu odluku Cañas se žalio Švicarskom federalnom sudu, tražeći poništenje odluke CAS-a iz razloga da su mu povrijeđena prava na pravično saslušanje kao i da je odlukom povrijeđen švicarski javni poredak.

U svom odgovoru, ATP je isticao prvenstveno razloge za odbačaj žalbe, pozivajući se na činjenicu da se igrač prava na žalbu odrekao, a podredno, ukoliko sud takav prigovor ne usvoji, tražio je odbijanje žalbe. Argument za odbačaj ATP je potkrijepio izvatkom iz ATP-pravila kao i dokumentom tiskanom na memorandumu ATP-a, naziva «PRISTANAK I SUGLASNOST IGRAČA NA PRAVILNIK ATP-a» (slobodan prijevod), potpisanom od strane Cañasa, koji sadrži izjavu kojom se isti obvezuje na poštovanje Pravila ATP-a uključujući i, ali ne ograničavajući se na, pravila za borbu protiv dopinga kao i sve dodatke navedenim pravilima za koje potvrđuje da ih je zaprimio i imao priliku proučiti. Nadalje, pristaje i slaže se da se svaki spor proizašao iz ili u vezi s pravilima Antidoping programa ATP-a, nakon iscrpljivanja internog pravnog puta pred Antidoping tribunalom, može temeljem žalbe odlučivati isključivo pred CAS-om, sve u roku od dvadeset i jedan dan od dana dostave odluke Antidoping tribunala. Postupak će se voditi u skladu s Pravilnikom CAS-a, čija odluka će biti konačna (bez mogućnosti preispitivanja i žalbe), kao i obvezujuća. Također, odriče se prava na podnošenje bilo kakvog zahtjeva s tim u vezi pred redovni sud, arbitražu ili bilo koje drugo tijelo.

U provedenom postupku Švicarski federalni sud iscrpno je preispitivao valjanost pristanka izraženog u ugovoru o arbitraži i pristanka izraženog na odricanje prava na poništavanje odluke CAS-a.

U odnosu na pristanak izražen na ugovor o arbitraži, odnosno preispitujući razloge za formalnu i materijalnu valjanost ugovora o arbitraži, nakon zaključka 
o ništavosti odricanja prava na poništavanje odluke izbranog suda u slučaju profesionalnih sportaša, sud je donio drugačiji zaključak. Pozivajući se na prijašnju praksu i uspoređujući ovaj slučaj sa slučajevima u kojima je ugovor o arbitraži sklopljen potpisom dokumenta u kojem se daje pristanak na poštovanje pravila koja sadržavaju arbitražnu klauzulu, odnosno uputom na arbitražnu klauzulu u sportskim sporovima, ${ }^{23}$ sud je utvrdio ugovor o arbitraži valjanim, naglašavajući postojanje liberalnog pristupa u praksi u odnosu na arbitražni ugovor u sportu. Iako je priznao da je možda na prvi pogled nelogično da se različita mjerila za valjanost pristanka primjenjuju za ugovor o arbitraži i ugovor o odricanju prava na poništavanje, takva nejednakost $u$ pristupu ima uporište $u$ potpori brzog rješavanja sporova u sportu od strane specijaliziranog tribunala koji jamči nezavisnost i nepristranost u odlučivanju. Međutim, puno važnije je utvrđenje suda kojim smatra pravo na poništavanje odluke izbranog suda protutežom liberalnom pristupu koji sudovi zauzimaju kada utvrđuju postojanje pretpostavki za valjanost ugovora o arbitraži u sportu, unatoč evidentnom nepostojanju potpune slobodne volje na sklapanje ugovora o arbitraži na strani sportaša.

U odnosu na meritum, sud je zaključio da je u postupku pred CAS-om arbitar propustio odlučiti o argumentu igrača o neusklađenosti Pravila ATP-a s pravom države Delaware, a da je isto odlučna činjenica za donošenje odluke, stoga je odluku vratio na ponovno odlučivanje.

Iz stajališta Švicarskog federalnog suda zauzetom u slučaju Cañas, može se zaključiti da je ništavost odredbe o odricanju prava na poništavanje pravorijeka protuteža pristupu prema valjanosti pristanka u arbitražnom ugovoru. Međutim, takvo obrazloženje nije potpuno uvjerljivo, uzimajući u obzir limitirane razloge iz kojih se može podnijeti žalba Švicarskom federalnom sudu a koji su propisani čl. 190 st. 2 PILA-e, i rijetku praksu istog suda kojom žalbu protiv odluke CAS-a usvaja.

Praktično se nadalje postavlja pitanje predstavlja li alternativa, koju pruža CAS kao forum za rješavanje sporova u sportu putem arbitraže, pravu alternativu redovnom sudu u smislu nepristranog i nezavisnog sudišta o čemu su već neki autori pisali (Baertsch, 2015.). Švicarski federalni sud već je u nekoliko svojih odluka preispitivao pruža li CAS mogućnost rješavanja sporova na jednak način kao i redovni sud ${ }^{24}$ te je posebno uzimao u obzir prednosti koje u usporedbi s redovnim sudom pruža $\mathrm{CAS}^{25}$ u sporovima vezanima uz sport. Bez obzira na takva stajališta,

23 Odluke Švicarskog federalnog suda: 4P.253/2003. od 25.03.2004. para 5.4., 4P.230/2000 od 7. II. 2001. para 2a i 4C.44/1996 od 31. X. 1996. para 3c, dostupno na http://www.bger.ch/fr.

24 Vidi: odluka Švicarskog federalnog suda broj 4P.217/1992 od 15. III. 1993. (Gundel v FEI), ATF 119 II $271 \mathrm{u}:$ Reeb, M., 1998.

25 Pitanje predstavlja li CAS nezavisni i nepristran način rješavanja sporova rano se postavilo $u$ praksi pred Śvicarskim federalnim sudom, te je isto potvrđeno uz konkretne primjedbe za eventualne buduće slučajeve. U to vrijeme osnivač CAS-a bio je Međunarodni olimpijski odbor, pa je sud, iako proglasivši CAS dovoljno nezavisnim od strane međunarodnih sportskih federacija u konkretnom slučaju, ipak naglasio da bi zaključak bio drugačiji da se kao stranka pojavi Međunarodni olimpijski odbor. Ova odluka dovela je do restrukturiranja organizacije CAS-a. ugovor nije valjan prema pravuno 67474/10di pravne učinke, iako je upravo tužiteljica bila ta koja je arbitražu pozivom na val 
isti je sud mjesno nadležan za preispitivanje zakonitosti pravorijeka CAS-a s obzirom na to da je sjedište CAS-a u Švicarskoj, stoga se takvo stajalište može uzimati kao praksa samo švicarskih sudova.

\subsection{Preispitivanje valjanosti ugovora o arbitraži u sportu primjenom Njujorške konvencije 1958. - slučaj Pechstein}

Pitanje postojanja i valjanosti ugovora o arbitraži, kao i mjerodavnog prava za ta pitanja, može se pojaviti pred arbitražnim vijećima i nacionalnim sudovima $u$ različitim fazama postupka. Tako se nacionalni sudovi mogu suočiti s tim pitanjima kada, na primjer (Lew, Mistelis, Kroell, 2015.):

- jedna stranka pokrene postupak pred redovnim sudom, a druga podnese prigovor nenadležnosti zbog postojanja ugovora o arbitraži;

- kada se od redovnog suda traži donošenje rješenja o privremenim mjerama ili drugim načinima kojima se iskazuje potpora arbitraži kao npr. osiguranje dokaza;

- kada stranka potraži zaštitu pred redovnim sudom radi imenovanja arbitra, jer je druga stranka to propustila učiniti ili odbija sudjelovati u postupku formiranja arbitražnog vijeća;

- u fazi nakon donošenja odluke, kada se odluka preispituje, poništava ili prisilno provodi pred nacionalnim sudom.

U praksi međunarodne sportske arbitraže rijetko će se pojaviti slučaj da je putem redovnog suda potrebno provesti odluku arbitraže. Ovo stoga što hijerarhijski sustav sportskih tijela i sportaša dozvoljava mogućnost provedbe takvih odluka s osnove članstva, članskih prava i obveza, odnosno unutarnjih propisa udruge. Iako je tome tako, novije vrijeme istaknulo je iznimke koje su uzdrmale dosad čvrsti sustav sportske arbitraže i jednostavne provedbe odluka.

Pitanje valjanosti arbitražnog ugovora usko je vezano uz pitanje provedbe arbitražnog pravorijeka. U sportskoj arbitražnoj praksi razlikuju se dva primjera primjene odredbi Njujorške konvencije u vezi s preispitivanjem valjanosti ugovora o arbitraži. Prvo, ako se stranka odrekla prava na žalbu na odluku izabranog suda sukladno čl. 190 st. 2 PILA-e, tada temeljem čl. 190 st 3 PILA-e u postupku priznanja odluke izbranog suda u Švicarskoj, Švicarski federalni sud primjenjuje odredbe i preispituje pretpostavke za valjanost ugovora o arbitraži primjenom Njujorške konvencije. Drugi je slučaj onda kada stranka traži priznanje i provedbu strane arbitražne odluke u državi različitoj od Švicarske (a država je potpisnica konvencije), te se u takvoj državi odluka koju je donio CAS koji ima sjedište u Švicarskoj, smatra stranim arbitražnim pravorijekom.

Pitanje valjanosti ugovora o arbitraži postavilo se u praksi u slučaju njemačke klizačice Claudie Pechstein, ali ne u fazi pokretanja arbitražnog postupka pa čak niti u fazi traženja priznanja i ovrhe arbitražne odluke, već u slučaju podnošenja tužbe za naknadu štete. Valjanost ugovora o arbitraži predstavljalo je prethodno pitanje radi utvrđivanja negativne procesne pretpostavke res iudicata. Naime, ako je arbitražni 
ugovor temeljem kojeg je donesena odluka među strankama zapravo ništav, on ne proizvodi pravne učinke, pa nema niti presuđene stvari iako je upravo Pechstein bila ta koja je arbitražu pozivom na valjani ugovor o arbitraži inicirala.

Činjenično, slučaj je vezan uz doping. U razdoblju između 2000. i 2009. godine, Pechstein je podvrgnuta brojnim doping kontrolama u natjecateljskom periodu (in-competition period) te izvan natjecanja (out-of-competition period), ali niti jedna kontrola nije rezultirala nalaskom zabranjene supstance u njezinu uzorku. Tijekom istog perioda, Međunarodna klizačka federacija (dalje: ISU) prikupila je više od devedeset uzoraka krvi Pechstein kao dio programa ISU-a za profiliranje krvi sportaša. Profiliranje krvi sastoji se u prikupljanju uzoraka krvi sportaša uz istovremeni unos rezultata analiza u bazu podataka - u tzv. biološku putovnicu, te se takvi podaci prate kroz određeno vrijeme i međusobno uspoređuju. Određene devijacije u rezultatima ukazuju na kršenje antidoping pravila jer jedino unos određene supstance ili korištenje određene metode može dati rezultat kakav je eventualno prikazan, osim ako ne postoji neko drugo objašnjenje (npr. bolest) što je sportaš u postupku dužan dokazati. Pechstein je jedna od prvih sportašica i sportaša uopće koji su se suočili s navodom o korištenju dopinga na temelju indikatora prikazanih u biološkoj putovnici sportaša. Naime, za vrijeme održavanja svjetskog prvenstva koje je organizirao ISU u Norveškoj, dan prije početka natjecanja (6. veljače 2009.) od svih sportaša sudionika uzeti su uzorci krvi radi skeniranja. Kako je vrijednost retikulocita ${ }^{26}$ bila iznad normalne, Pechstein je sljedeći dan još dva puta podvrgnuta uzimanju uzoraka krvi, te su oba nalaza davala jednak rezultat. Nekoliko dana poslije, uzet je novi uzorak te je nalaz bio uredan. Na temelju nalaza iz biološke putovnice, Pechstein je, zbog kršenja antidoping pravila, od strane ISU-a sankcionirana određivanjem razdoblja nepodobnosti u trajanju od dvije godine. ${ }^{27} \mathrm{Na}$ takvu odluku Pechstein je podnijela žalbu CAS-u, temeljeći nadležnost CAS-a na ugovoru o arbitraži sklopljenom putem zahtjeva za izdavanjem licence nacionalne i međunarodne federacije. Pred CAS-om se kao spornima postavilo nekoliko pitanja.

U odnosu na teret i standard dokazivanja, sporno je bilo pitanje primjenjuje li se u ovakvom slučaju presumpcija o kršenju pravila kao kod pitanja kršenja pravila koja proizlaze iz analize uzorka kada je direktno u tom uzorku nađena zabranjena supstanca, ili je posljednje ipak potrebno dokazivati. CAS je zauzeo stajalište da u antidoping proceduri koja nije rezultat direktnog pozitivnog nalaza na zabranjenu supstancu ili metodu, sportska organizacija nema lak zadatak u dokazivanju da je počinjeno kršenje antidoping pravila jer se u takvom slučaju ne primjenjuje presumpcija kršenja već je kršenje potrebno dokazivati, dok namjeru ili krivnju ISU ne treba dokazivati s obzirom na to da je usvojen princip stroge odgovornosti i da se radi o navodu za korištenje zabranjene metode a ne za korištenje u pokušaju. Kao sporan, postavio se i standard dokazivanja jer je Pechstein tvrdila da standard dokaza za činjenicu kršenja mora biti blizu standardu kaznenog prava kojim se

26 Nezrela krvna zrnca koja ispušta koštana srž.

27 Sve sukladno Kodeksu WADA koji je na snazi bio od 1. I. 2009. - 31. XII. 2014. i koji je za takvo kršenje antidoping pravila predviđao sankciju od dvije godine. 
dokazuje činjenica izvan svake sumnje. CAS je obrazložio da je test «razine izvjesnosti» ${ }^{28}$ opće poznat u praksi CAS-a, čak i u periodu prije stupanja na snagu prvog Kodeksa WADA-e, ${ }^{29}$ da je pravilnost iste primjene potvrđena i praksom Śvicarskog federalnog suda koji je više puta istaknuo razliku između kaznenih postupaka i disciplinskih postupaka u sportu. Disciplinski postupci u sportu privatni su civilni postupci što u praksi znači da se problem dokazivanja ne može rješavati primjenom principa i instituta kaznenog prava. Pechstein je osporavala i urednost procesa prikupljanja uzoraka krvi, međutim, CAS je odlučio da se dokumentacija, u odnosu na koju se Pechstein pozivala na prekršeni postupak prikupljanja, uopće ne primjenjuje na postupak skeniranja krvi, a spornim se postavilo i pitanje urednosti lanca držanja prikupljenih uzoraka, od trenutka prikupljanja do laboratorija, također bezuspješno. U odnosu na osobne vrijednosti iz krvi Claudie Pechstein, CAS je cijenio odnos vrijednosti Claudie Pechstein prema vrijednostima drugih ljudi, ali i prema njezinim ostalim vrijednostima iz ranije uzetih uzoraka, te potencijalna objašnjenja za nalaz. Nalazi koji su predmet spora bili su atipični, kako u odnosu na nalaze drugih sportaša klizača u zadnjem desetljeću, ali i u odnosu na ranije nalaze same sportašice. CAS je nakon iscrpno provedenog dokaznog postupka na okolnost svakog od prigovora te saslušanja brojnih vještaka hematologa, došao do zaključka da svi dokazi idu u prilog tvrdnji ISU-a koji je uvjerio arbitražno vijeće da nema razumnog objašnjenja za abnormalne nalaze u krvi Claudie Pechstein osim onog da se ista podvrgnula krvnom dopingu. Kako pitanje nadležnosti i valjanosti ugovora o arbitraži uopće nije postavljeno kao sporno, jer je upravo Pechstein pokrenula žalbeni arbitražni postupak, temeljeći nadležnost na dobrovoljnoj registraciji za natjecanje na kojem su uzeti sporni nalazi, a time i na pristanak na sva pravila ISU-a, uključujući i antidoping pravila i pravila za rješavanje sporova arbitražom, a ISU u postupku pred CAS-om to nije osporio, nadležnost CAS-a nije bila upitna. Slijedom navedenoga, CAS je odbio žalbu Pechstein i potvrdio razdoblje nepodobnosti u trajanju od dvije godine. ${ }^{30}$ Pechstein je daljnju zaštitu potražila pred Švicarskim federalnim sudom, i to dvaput, u postupku povodom revizije te u postupku žalbe, oba puta bezuspješno. ${ }^{31}$

Nakon odluke Švicarskog federalnog suda, Pechstein je protiv Švicarske pokrenula postupak pred Europskim sudom za ljudska prava koji je još uvijek u tijeku. ${ }^{32}$

U međuvremenu, iako je potpisala ugovor o arbitraži kojim se obvezuje sve buduće sporove s ISU-om podnijeti na definitivno odlučivanje isključivo pred CAS i činjenicu da je CAS već odbio njezinu žalbu na odluku ISU-a, Pechstein je 2012.

28 Originalni termin ,balance of probabilities“, slobodan prijevod.

29 01. I. 2004. godine.

30 CAS 2009/A/1912 \& 1913 od 25. XI. 2009., CAS Bulletin 1/2011, str. 134-147, dostupno na www.tas-cas.org.

31 Odluka Švicarskog federalnog suda 4A_612/2009 od 10. II. 2009. i 4A_144/2010 od 28. IX. 2010., dostupno na http://www.bger.ch/fr.

32 Europski sud za ljudska prava (ECHR), Claudia Pechstein v Switzerland, no 67474/10, http:// www.echr.coe.int/Documents/FS_Sport_ENG.pdf, zadnje posjećeno 01. VI. 2016. 
godine podnijela tužbu Općinskom sudu u Münchenu u Njemačkoj. ${ }^{33}$ Zahtjev je usmjerila na obvezu ISU-a na isplatu na ime naknade štete temeljem činjenice da je sankcija kojom ISU 2009. godine izriče razdoblje nepodobnosti zapravo ništava. U ovoj fazi postupka, na teritoriju države potpisnice Njujorške konvencije (Njemačke) počet će druga faza duge borbe Pechstein i to na drugoj pravnoj osnovi, onoj primjenom Njujorške konvencije. ${ }^{34}$

Njujorška konvencija u čl. II. propisuje da svaka država ugovornica priznaje pismeni ugovor kojim se stranke obvezuju staviti u nadležnost arbitraži sve sporove ili neke od sporova koji nastanu ili bi mogli nastati između njih po određenom pravnom odnosu, ugovornom ili neugovornom, a koji se odnosi na pitanje koje je prikladno za rješavanje arbitražom. Pod pismenim sporazumom razumijevaju se arbitražna klauzula unesena u ugovor ili kompromis koje su potpisale stranke ili su sadržani u razmijenjenim pismima ili brzojavima. Sud države ugovornice kojem je podnesen na rješavanje spor o nekom pitanju o kojem su stranke sklopile ugovor o arbitraži, uputit će stranke na arbitražu (osim ako ustanovi da je taj ugovor prestao biti valjan, da je bez učinka ili neprikladan za primjenu). Dalje, Njujorška konvencija u čl. V. (a) propisuje da se priznanje i ovrha strane arbitražne odluke mogu odbiti ako stranka protiv koje se priznanje traži, nadležnom tijelu koje o priznanju i ovrsi odlučuje, dokaže da su stranke ugovora o arbitraži prema pravu koje se na njih primjenjuje bile nesposobne za sklapanje ili da ugovor nije valjan prema pravu koje su stranke za ugovor o arbitraži izabrale kao mjerodavno, a ako nisu izabrale mjerodavno pravo, prema pravu države gdje je odluka donesena. U prvostupanjskom postupku, Općinski sud u Münchenu odlučio je ${ }^{35}$ da je ugovor o arbitraži koji je Pechstein sklopila s međunarodnom klizačkom federacijom (ISU) ništav jer je sklopljen pod prisilom s obrazloženjem da je jedina mogućnost da Pechstein nastupi na natjecanju koji organizira ISU bila sklapanje ugovora o arbitraži. Slijedom navedenoga, a s obzirom na to da takav ugovor o arbitraži ne ispunjava sve uvjete propisane čl. 6. ECHR-a ${ }^{36}$ (pravo na pravično suđenje), a posebno u odnosu na manjkavost u nezavisnosti CAS-a ukazujući na izborni sustav temeljem kojega su imenovani arbitri i predsjednici arbitražnih vijeća na CAS-u. Ovakav stav obrazložio je sud sljedećim argumentima. Prvenstveno, arbitri se imenuju sa zatvorene liste, na kojoj je samo 1/5 arbitara imenovana uzimajući interese sportaša, a da sportaši uopće nemaju pravo imenovanja arbitara na zatvorenu listu, što kao posljedicu ima prevlast sportskih federacija i drugih sportskih tijela na CAS-u kao instituciju. ${ }^{37}$ Drugo, predsjednika arbitražnog vijeća od ukupno tri arbitra, u žalbenom arbitražnom postupku imenuje predsjednik žalbenog odjela, koji postupak, smatra sud, nije dovoljno transparentan jer stranke zapravo ne znaju

33 Originalan naziv suda glasi: Landesgericht München.

34 http://www.uncitral.org/pdf/english/texts/arbitration/NY-conv/New-York-Convention-E.pdf, zadnje posjećeno 17. V. 2016.

35 LG München I, 26. II. 2014-37 = 28331/12 dostupno na www.dejure.org.

$36 \mathrm{http} / / /$ conventions.coe.int/Treaty/en/Treaties/Html/005.htm, zadnje posjećeno 17. V. 2016.

37 Članak S4 CAS Kodeksa u slobodnom prijevodu propisuje: „ICAS je sastavljen od dvadeset članova, iskusnih pravnika imenovanih na sljedeći način: 
zašto je koji arbitar imenovan kao predsjednik arbitražnog vijeća. Međutim, bez obzira na navedenu argumentaciju, Općinski sud u Münchenu odbacio je tužbu Claudie Pechstein sukladno principu «res iudicata», smatrajući da mu je zabranjeno odlučivati o meritumu jer je o istom već odlučivao CAS koji je utvrdio valjanom sankciju što ju je izrekao ISU. Također, u odnosu na pitanje priznanja odluke CAS-a, sud je zaključio da je obvezan istu priznati primjenom čl. V. Njujorške konvencije dok se prigovor ništavosti ugovora o arbitraži ne može uzeti u razmatranje s obzirom na to da je upravo Pechstein ta koja je inicirala postupak pred CAS-om, pozivajući se na sklopljen ugovor o arbitraži. Pechstein se na odluku Općinskog suda u Münchenu žalila Višem regionalnom sudu u Münchenu koji je žalbu usvojio i preinačio prvostupanjsku odluku. ${ }^{38}$ Iz obrazloženja odluke slijedi da sud smatra da je ugovor o arbitraži kojim se sporovi podvrgavaju na odlučivanje pred CAS ništav, stoga da je i odluka CAS-a koja se na takvom ugovoru temelji ništava. Sud je istaknuo ono što se zapravo vrlo često zanemaruje u analizama djelatnosti sportskih udruga, a to je da su one monopolisti određenog tržišta. Ako se uzme u obzir da sportaši određenog sporta tim sportom zarađuju za život, tada njihovo djelovanje na profesionalnom nivou čini vrstu rada, dakle pripadnost tržištu rada u određenoj industriji. Kako sportske udruge kontroliraju tržište na kojem se odvijaju međunarodna sportska natjecanja, a rezultat tih natjecanja strogo je vezan uz visinu vrijednosti rada sportaša (prihode), niti jedan sportaš, ako se želi aktivno i profesionalno baviti sportom, ne može sebi priuštiti da na natjecanjima ne sudjeluje. Zaključno da je ugovor o arbitraži, sklopljen na način na koji je sklopljen onaj između Claudie Pechstein i ISU-a, suprotan odjeljku $19^{39}$ njemačkog zakona za zaštitu tržišnog natjecanja ${ }^{40}$ koji zabranjuje društvima zloupotrebu dominantnog položaja na određenom tržištu. Međutim, zanimljivo je, sud nije smatrao da ugovor o arbitraži, koji je zapravo nametnut sportašima, per se čini kršenje zabrane iskorištavanja monopolističkog položaja. U ovom smislu sud je zaključio da, iako su u dominantnom položaju na tržištu, sportskim federacijama je dozvoljeno prisiliti sportaše na rješavanje sporova putem arbitraže, uzimajući u obzir posebnosti industrije i sportskog tržišta, a posebno dosljednosti u načinu odlučivanja

1. Četiri člana imenuju Međunarodne federacije i to: tri Udruženje Međunarodnih federacija ljetnih olimpijskih sportova (ASOIF) i jednog Udruženje Međunarodnih federacija zimskih olimpijskih sportova (AIOWIF), koji se biraju unutar ili izvan njihovog članstva;

2. Četiri člana imenuje Udruženje nacionalnih olimpijskih odbora (ANOC) koji se biraju unutar ili izvan njihovog članstva;

3. Četiri člana imenuje Međunarodni olimpijski odbor (IOC) koji se biraju unutar ili izvan njegovog članstva;

4. Četiri člana imenuju dvanaest članova ICAS-a iz prethodna tri stavka ovog članka, nakon posebnih konzultacija a imajući u vidu zaštita interesa sportaša;

5. Četiri člana imenuju šesnaest članova ICAS-a iz prethodna četiri stavka ovog članka, izabranih među kandidatima nezavisnih od tijela koje imenuju članove ICAS-a.“

38 OLG München, 15. I. 2015. - U 1110/14 Kart., dostupno na https://dejure.org/dienste/vernetzung/ rechtsprechung?Gericht $=\mathrm{OLG} \% 20 \mathrm{M} \% \mathrm{FCnchen} \&$ Datum=15.01.2015\&Aktenzeichen $=\mathrm{U} \% 201110 / 14$.

39 Section 19 Germain Cartel Law, slobodan prijevod.

40 Act agains Restraints on Competition, http://www.gesetze-im-internet.de/englisch_gwb/, zadnje posjećeno 17. V. 2016. 
u pravnim stvarima vezanima za doping, ali da tadašnja struktura CAS-a ${ }^{41}$ vodi u zlouporabu dominantnog položaja na tržištu jer je ICAS, koji imenuje arbitre CAS-a na zatvorenu listu, sastavljen od većine predstavnika sportskih federacija, što nezavisnost i nepristranost CAS-a čini upitnima. Također, drugostupanjski je sud potvrdio ispravnim stajalište u odnosu na proceduru imenovanja predsjednika arbitražnog vijeća, kojega, u nedostatku izričitog dogovora stranaka, u redovnom postupku CAS- $\mathrm{a}^{42}$ imenuje na netransparentan način predsjednik odjela koji je i sam imenovan od ICAS-a kao tijela u kojem većinu glasova imaju sportske federacije. Vezano za pitanje primjene Njujorške konvencije, drugostupanjski sud utvrdio je da nije dužan priznati odluku CAS-a, da bi priznanje odluke CAS-a bilo protivno javnom poretku Njemačke jer bi ISU ovjekovječio zloupotrebu vladajućeg položaja na tržištu temeljem ugovora o arbitraži, već je dužan primijeniti članak V., ali stavak 2 (b) koji propisuje da se priznanje i ovrha arbitražne odluke mogu odbiti ako nadležno tijelo pred kojim se priznanje i ovrha traže ustanovi da bi to bilo protivno javnom interesu.

Pitanje pozivanja na ništavost ugovora o arbitraži od strane osobe koja je upravo na tom ugovoru temeljila prethodni postupak iz kojeg je proizašla odluka, sud nije razmatrao. Sud je zaključio da niti nezavisnost arbitražnog vijeća niti pravičnost procedure ne može biti garantirana sportašu, a ako se navedeno stavi u vezu s monopolističkim položajem koji nedvojbeno imaju sportske udruge na tržištu, arbitražna klauzula koja je nametnuta sportašima onemogućava sportaša na ustavno pravo pristupa sudu, što je sve zajedno protivno kako njemačkom pravu, tako i ECHR-u. ISU se na odluku žalio njemačkom Bundesgerichshofu.

Dana 7. lipnja 2016. njemački Bundesgerichsthof (dalje: BGH) priopćio je medijima odluku u slučaju Pechstein. ${ }^{43}$ Odluka predstavlja najvažniju odluku u arbitražnom svijetu vezanom za sport jer je ujedno i prva takva odluka prema kojoj se jedan redovni sud bavio CAS-om i valjanosti sustava koji na njemu počiva ugovorom o arbitraži u pravnim stvarima vezanima uz sport. Iz priopćenja proizlazi da je sud zauzeo stajalište kojim je odbio argumentaciju što ju je postavila Pechstein, te odbacio tužbu s obzirom na postojanje ugovora o arbitraži. Obrazloženje suda temelji se na sljedećim postavkama:

(i) iako je Svjetska klizačka federacija monopolist u organizaciji natjecanja matičnog sporta, odgovor na pitanje predstavlja li zahtjev za potpisivanje ugovora o arbitraži u korist nadležnosti CAS-a zlouporabu, ovisi o vaganju interesa stranaka, a kao rezultat sud nije utvrdio zloupotrebu dominantnog položaja;

(ii) CAS je pravi arbitražni sud u smislu njemačkog zakona o parničnom postupku (čl. 1025. ZPO: German Code of Civil Procedure);

(iii) zatvorena lista s koje se arbitri biraju, niti činjenica da takvu listu sastavlja tijelo koje je pretežito sastavljeno od predstavnika međunarodnih federacija

${ }_{41}$ Struktura kakva je bila temeljem propisa na snazi u vrijeme postupka koji je vodila Pechstein, a koji su naknadnim izmjenama promijenjeni.

${ }^{42}$ A uvijek u žalbenom postupku CAS-a.

43 Vidi priopćenje za medije http://www.rdes.it/Decision\%20Pechstein\%20Case.pdf. 
i olimpijskih odbora ne umanjuju činjenicu da CAS ispunjava uvjete koje za arbitražni sud propisuje ZPO; naime takva odredba ne predstavlja neuravnoteženost s obzirom na to da je borba protiv dopinga zajednički interes sportaša i federacija; korist postojanja specijaliziranog međunarodnog arbitražnog tijela očituje se u ujednačenim standardima i brzom donošenju odluka te su te koristi jednako važne za federacije koliko i za sportaše; sva preostala neravnoteža u korist federacija balansirana je Pravilnikom CAS-a koji osigurava individualnu nepristranost i nezavisnost arbitara; federacija koja je stranka u postupku bira jednog arbitra, a sportaš drugog sa liste, dok izabrani arbitri zajedno biraju predsjednika vijeća te arbitra koji se doima pristranim može se odbiti; nezadovoljna stranka uvijek može zatražiti zaštitu pred Śvicarskim federalnim sudom koji odluku može poništiti;

(iv) ugovor o arbitraži potpisan je dobrovoljno; to što je tužiteljica postupala kako joj je nametnula druga strana jer da se u suprotnom ne bi mogla natjecati, ne čini ugovor o arbitraži ništavim jer je, nakon vaganja interesa obiju strana, utvrđeno opravdanim korištenje arbitražne klauzule koja nije suprotna vrijednostima što proizlaze iz prava;

(v) pravo na pristup pravdi kao i pravo na bavljenje sportskom profesijom mora biti odvagnuto u odnosu na autonomiju sportske federacije; također, zajamčeno je i pravo pristupa Švicarskom federalnom sudu tako da pravo na pristup njemačkim sudovima ne postoji.

\section{ZAKLJUČAK}

Stajalište BHG-a izazvalo je različite reakcije. Neki autori smatrali su da je stajalište suda kako je sklapanje ugovora «dobrovoljno iako je nametnuto od drugih», najblaže rečeno, začuđujuće ako se uzme u obzir očit neravnopravni položaj između stranaka (DeMarco, 2016.). U slučaju u kojem je položaj stranaka takav da sredstva za život jedne stranke ovisi o dozvoli sportske federacije da se natječe, postavlja se pitanje kako je moguće zaključiti da je pristanak na arbitražu dan dobrovoljno, te ako se prizna takav neravnopravan status sportaša, zašto im se ne pruža adekvatna zaštita u odnosu na nepoštene ugovore. Upravo je na tim temeljima i Pechstein tražila zaštitu pred ustavnim sudom u Njemačkoj. ${ }^{44} \mathrm{Bez}$ obzira na krajnji ishod slučaja Pechstein, isti je pokrenuo dublje debate koje su dovele do zahtjeva za organizacijskom i strukturalnom promjenom CAS-a. ${ }^{45}$ Čak je i sam CAS u priopćenju za javnost istaknuo da razmatra reformu i da je voljan slušati i analizirati prijedloge svojih korisnika, i sudaca i pravnih stručnjaka, kako bi nastavio razvitak te u poboljšanju rastao s promjenama u međunarodnom sportu

44 Više o tome vidi u pripćenju Claudie Pechstein: http://www.sportsintegrityinitiative.com/analysispechstein-to-appeal-after-german-court-throws-out-her-case/.

45 Takve zahtjeve postavilo je više udruga sportaša. Npr. vidi: http://www.uniglobalunion.org/news/ players-will-continue-claudia-pechsteins- heroic-fight-reform-sports-justice-system; FIFPro: https:// fifpro.org/en/news/despite-decision- pechstein-must-trigger-reform, https://fifpro.org/en/news/doesfootball-need-cas. 
i dobrom praksom međunarodnog arbitražnog prava u kojem smjeru bi reforme bile usmjerene. ${ }^{46}$ Reforme što ih neki autori predlažu odnose se na reformu sustava imenovanja arbitara, pravnu pomoć, objavu odluka i ustanovljavanja domaćih arbitražnih tijela (De Marco, 2016.).

Zaključno, iz slučaja Pechstein može se zaključiti da su temelje međunarodne sportske arbitraže poljuljali zapravo oni sudionici koji godinama nisu htjeli ili nisu znali regulirati organizaciju sportskog sektora i pravila koja uređuju sport. Naime, države i državna tijela tijekom povijesti priznavale su, iako nekad nevoljko, autonomiju privatnih sportskih organizacija da uređuju područje svojeg djelovanja, obrazlažući to nedostatkom znanja javnog sektora o sportu te oportunosti rješenja da će upravo privatni sportski sektor koji ima najviše znanja ta pitanja najbolje i urediti. Upletanje javnog sektora u privatni sportski, i polako ali sigurno ocrtavanje granica autonomije odlučivanja sportskih udruga razvijalo se postupno s rastom vrijednosti sportskih ugovora, pa se nakon poznatih slučajeva Meca-Medina i Majcen te slučaja Bosman, može svjedočiti i prilagodbi internih privatnih propisa javnopravnim zahtjevima. Može se opisati logičnim da osoba koja se bavi djelatnošću od koje živi mora imati jednaka temeljna prava kao i svaki drugi radnik izvan sportske industrije. Također, može se zaključiti i o postojanju opće potpore arbitraže kao alternativnog rješavanja sporova u sportu sve dok se poštuju temeljna ljudska prava i slobode, jer ipak postoji pretežit konsenzus o potrebi konzistentnosti u odlučivanju primjenom specijaliziranog područja prava kakva su neka pravila koja uređuju sport. Analizirajući posebno pravila za sprečavanje dopinga u sportu, dolazi se do zaključka da se rijetko u svijetu jedan privatni ugovor, kakav je to Svjetski antidopinški kodeks ili Kodeks WADA-e, primjenjuje na milijunsku populaciju međunarodnog obilježja. Interesi koje isti štiti, a to su prvenstveno interesi sportaša koji ne varaju, teško da bi se na globalnom nivou jednako mogli zaštititi drugačijim uređenjem. Kada dođe do kršenja takvih pravila, ista propisuju jednake sankcije za sve koji ih prekrše i jednak način rješavanja sporova putem specijaliziranog suda. Slijedom navedenoga, upletanje jednog nacionalnog suda, i to države potpisnice Konvencije za borbu protiv dopinga u sportu UNESCO-a (dalje UNESCO Konvencija), ${ }^{47}$ koja je, kao 56. po redu, 31. V. 2007. ratificirala konvenciju kojom se izričito obvezuje implementirati antidoping strategiju u nacionalno zakonodavstvo koja se naslanja i spominje Kodeks WADA-e, na način kako je to odlučio Viši regionalni sud u Münchenu u slučaju Pechstein, zahtijeva kritiku. Naime, iako o pitanju vezanosti suda međunarodnim ugovorom kakav je to UNESCO Konvencija, nije u presudi bilo govora, ostaje uvijek za preispitati pitanje trenutka u kojem je sud odlučio preispitivati valjanost ugovora o arbitraži kao i pitanje stranke koja takav prigovor iznosi. Naime, ako se uzme u obzir da sudovi i arbitražna tijela gotovo ustaljeno $\mathrm{u}$ arbitražama smatraju da se osoba koja se upustila u razmatranje merituma u postupku, a nije istakla prigovor nenadležnosti, smatra da je na nadležnost prešutno

\footnotetext{
46 Više o tome vidi: http://www.tas-cas.org/fileadmin/user_upload/Media_Release Pechstein_07.06.16_English_.pdf.

47 www.unesco.org, http://www.unesco.org/new/en/social-and-human-sciences/themes/anti-doping/ international-convention-against-doping-in-sport/
} 
pristala, teško je prihvatiti stajalište suda koji usvaja prigovor ništavosti ugovora o arbitraži na koji se pozvala sama kada je određeni postupak započinjala. Naime, čak i da je ugovor o arbitraži ništav onakav kakav je u pismenoj formi u slučaju Pechstein zaključen temeljem ponude i prihvatu ponude izražene u licenci i prihvaćanju licence i propisa, može se zaključiti da je Claudia Pechstein, podnijevši žalbu na odluku ISU-a pred CAS, dala novu ponudu za sklapanje ugovora o arbitraži koja je neosporavanjem nadležnosti od strane ISU-a prihvaćena. Dakle, ugovor o arbitraži u takvom slučaju sklopljen je prešutno, ali obrnutim slijedom. U svakom slučaju, Pechstein je ili podnošenjem žalbe na CAS postala ponuditelj, ili je, pozivajući se na valjani ugovor o arbitraži kao temelju za nadležnost u rješavanju po žalbi, izgubila pravo na osporavanje nadležnosti CAS-a. Drugačije stanje stvari moglo bi proizaći iz situacije da je Pechstein pokrenula postupak pred redovnim sudom prije CAS-a, da je ISU istakao prigovor nenadležnosti redovnog suda, a redovni sud je odlučujući o svojoj nadležnosti odlučivao o postojanju valjanog ugovora o arbitraži. Međutim, činjenica da osoba sama traži zaštitu svojih prava putem arbitraže, vodi postupak o meritumu, ne koristi svoja prava na traženje izuzeća arbitra niti prigovora nenadležnosti, te onda naknadno tek u fazi pred nacionalnim sudom o pitanju priznanja arbitražne odluke ističe prigovore, pravno je upitno. Jednako tako, upitan je i stav suda države koja takve prigovore usvoji, a koja je ratificirala konvenciju koja spominje i naslanja se na Kodeks WADA-e, iz čijeg sadržaja izravno proizlazi arbitražna klauzula u korist CAS-a, te kojom konvencijom je sadržaj privatnopravnog ugovora stavljen u javno-pravnu sferu. ${ }^{48}$ Ovo posebno čudi jer je Njemačka jedna od zemalja s najstrožom politikom prema dopingu, pa je tako jedna od prvih država $^{49}$ koja je još 2006. pokrenula postupak donošenja zakona prema kojem će korištenje dopinga biti kazneno djelo koje se kažnjava kaznom zatvora. ${ }^{50}$ Takav Antidoping zakon Njemačke danas je na snazi. ${ }^{51}$ Međutim, iako je BHB ispravio većinu od kritiziranog, i odluka BHG-a zahtijeva kritiku. Dikcija odluke koja u jednoj rečenici iznosi tvrdnju kako je ugovor o arbitraži sklopljen dobrovoljno, iako je nametnut, nije posve logična. Iako se ishod odluke može smatrati pravilnim, razlozi koji su temelj takve odluke nisu se temeljili na nespornim činjenicama da je upravo Pechstein bila ta koja je inicirala arbitražni postupak te iscrpila redovni pravni put sve do Švicarskog federalnog suda, pa da bi se zato arbitražni ugovor smatrao valjanim. Suprotno, BGH svoje je obrazloženje temeljio na jednoj fazi ranije - na trenutku prihvata nametnute ponude bez kojega se Pechstein ne bi mogla natjecati.

Bez obzira na odluke koje su sudovi donijeli u ovoj pravnoj stvari, važnost slučaja Pechstein očituje se u činjenici da je ovo prvi poznati slučaj u kojem je jedan redovni sud države potpisnice Njujorške konvencije i potpisnice UNESCO

48 Konvencija UNESCO-a protiv dopinga u sportu, potvrđena u Hrvatskoj Zakonom o potvrđivanju međunarodne konvencije protiv dopinga u sportu, NN MU 7/2007, www.nn.hr, u čl. 4 propisuje odnos Konvencije prema Kodeksu.

49 Zajedno s Italijom, Francuskom i Japanom.

50 Dostupno na http://www.bmjv.de/SharedDocs/Zitate/DE/2015/11132015_BT_Anti-Doping.html. 
konvencije za borbu protiv dopinga razmatrao valjanost ugovora o arbitraži kakav se redovno u sportskom svijetu sklapa, u slučaju kada je arbitražni postupak inicirala sportašica koja se na valjanost takvog ugovora pozvala upravo u trenutku kada je inicirala postupak pred CAS-om. Sportska zajednica s nestrpljenjem je iščekivala odluku BGH-a, svjesna posljedica koje će takva odluka imati za budućnost sportske arbitraže, ali i za naglašavanje postojećih manjkavosti koje će poželjno dovesti do reformi i poboljšanja sustava. Jednako tako željno iščekuje i presudu Europskog suda za ljudska prava koji će u predmetu Pechstein preispitivati valjanost ugovora o arbitraži u smislu valjanosti odricanja prava na pristup sudu (čl. 6.). Naime, sukladno praksi ECHR-a, odricanje prava na pristup sudu da bi bilo valjano mora biti dobrovoljno i bez prisile, ali ne znači da je svaka obvezatna arbitraža protivna čl. 6. ECHR-a već je dopustiva ona koja je sukladna načelu proporcionalnosti i interesu dobrog služenja pravdi.

\section{BIBLIOGRAFIJA}

1. Lew, D M Julian; Mistelis, Loukas A.; Kroell, Stefan M., Comparative International Commercial Arbitration, Nizozemska, 2003., str. 130

2. Odluka francuskog suda Cour d'appel Paris, 8 June 1995, Sarl Centro Stoccagio Grani v SA Granit u: Lew, D. M. Julian; Mistelis, Loukas A.; Kroell, Stefan M., Comparative International Commercial Arbitration, Nizozemska, 2003., str. 130 .

3. Model-zakon iz 1985., s amandmanom iz 2006., dostupno na: http://www. uncitral.org/uncitral/en/uncitral_texts/arbitration/1985Model_arbitration.html, zadnje posjećeno 19. V. 2016.

4. Zivilprocessordnung, S1031 Form der Schiedsverienbarung, dostupno na: https://www.gesetze-im-internet.de/bundesrecht/zpo/gesamt.pdf.

5. New York Convention 1958., dostupno na: http://www. newyorkconvention1958.org/index.php?lvl=notice_display\&id=564.

6. The Code of the Court of Arbitration for Sport, dostupno na: www.tas-cas.org.

7. Swiss Private International Law Act (PILA), dostupno na: https://www. swissarbitration.org.

8. Swiss Tribunal Federal, Tradax Export SA (Panama) v Amoco Iranian Oil Company, od 7. veljače 1984., dostupno na: http://www.bger.ch/fr.

9. Swiss Tribunal Federal, Campagnie de Navigation et Transport v MSC od 16. siječnja 1995., para 13, dostupno na http://www.bger.ch/fr.

10. CAS 2012/A/2747 od 15.04.2013., WADA v. Judo Bond Nederland, Dennis de Goede \& Dopingautoriteit, dostupno na: www.tas-cas.org.

11. ATF 4A_640/2010 od 18. travnja 2010., A. V. WADA, FIFA \& CFA, dostupno na http://www.swissarbitrationdecisions.com. 
12. Reeb, M. (2002.), Digest of CAS Awards II 1998-2000, Švicarska.

13. Reeb, M. (1998.) Digest of CAS Awards II 1986-1998, Švicarska.

14. CAS 2009/A/1910 odluka o nadležnosti od 09. IX. 2010. para.4.8. i 4.25, www. tas-cas.org.

15. CAS 2012/A/2813 od 23.01.2013., www.tas-cas.org.

16. Mavromati, D. i Reeb, M. (2015.), The Code of the Court of Arbitration for Sport-Commentary, Cases, and Materials, Nizozemska.

17. CAS 2003/O/502 od 29. X. 2003., para 4.1, www.tas-cas.org.

18. ATF 4P.253/2003 od 25. III. 2004., http://www.bger.ch/fr.

19. ATF 4P.162/2003 od 21. XI. 2003., http://www.bger.ch/fr.

20. Rigozzi, A. i Robert-Tissot, F. (2015.), ,'Consent' in Sports Arbitration: Its Multiple Aspects“, u: Sports Arbitration: A Coach for Other Players?, Association Suisse de l'Arbitrage, ASA Special Series No. 41.

21. Stretford v. Football Association Ltd, High Court (Chancery) (EWHC (CH) 479 (2006.), objavljeno u I.S.L.R.SLR39-48, 46-47, paras 42,45,48.

22. CAS 2012/A/2813 od 23. I. 2013., www.tas-cas.org.

23. 13/11-VSA od 13. IV. 2012., uvid u spis u Tajništvu Vijeća sportske arbitraže Hrvatskog olimpijskog odbora.

24. Geisinger, E. i Trabaldo de-Mestral, E. (2015.) Sports Arbitration: A Coach for Other Players?, Association Suisse de 1'Arbitrage, ASA Special Series No. 41.

25. Baertsch, P. (2015.), ,'Consent' in Sports Arbitration:Which Lessons for Arbitration Based on Clauses in Bylaws, Corporation, Associations, etc.?" u: Sports Arbitration: A Coach for Other Players?, Association Suisse de l'Arbitrage, ASA Special Series No. 41.

26. 4P.217/1992 od 15. III. 1993. (Gundel v FEI), ATF 119 II 271 u Reeb, M. (1998.), Digest of CAS Awards II 1986-1998, Švicarska, 1998.

27. CAS 2009/A/1912 \& 1913 od 25. XI. 2009., CAS Bulletin 1/2011, dostupno na: www.tas-cas.org.

28. 4A_612/2009 od 10. II. 2009. i 4A_144/2010 od 28. IX. 2010. dostupno na: http://www.bger.ch/fr.

29. Europski sud za ljudska prava (ECHR), Claudia Pechstein v Switzerland, no 67474/10, dostupno na: http://www.echr.coe.int/Documents/FS_Sport_ENG. pdf, zadnje posjećeno 01. VI. 2016.

30. OLG München I, 26. II. 2014.-37 O 28331/12 dostupno na www.dejure.org.

31. OLG München, 15. I. 2015 - U 1110/14. Kart.,https://dejure.org/dienste/ vernetzung/rechtsprechung?Gericht=OLG\%20M\%FCnchen\&Datum=15.01.201 5\&Aktenzeichen=U\%201110/14, zadnje posjećeno 01. VI. 2016.

32. Act agains Restraints on Competition, dostupno na: http://www.gesetze-im- 
Petra Pocrnić Perica: Ugovor o arbitraži u pravnim stvarima vezanima uz međunarodni sport Zbornik radova Pravnog fakulteta u Splitu, god. 54, 2/2017., str. 457.- 481.

internet.de/englisch_gwb/, zadnje posjećeno 17. V. 2016.

33. http://www.rdes.it/Decision\%20Pechstein\%20Case.pdf.

34. http://www.sportsintegrityinitiative.com/analysis-

pechstein-to-appeal-after-german-court-throws-out-her-case/

35. De Marco, N. (2016.), Compelled consent -Pechstein \& the Dichtonomy and Future of Sports Arbitration, dostupno na: https://www.google.hr/url?sa=t\&rct= $\mathrm{j} \& \mathrm{q}=\&$ esrc $=$ s\&source $=$ web $\& \mathrm{~cd}=3 \&$ ved $=0$ ahUKEwiUmqfMqMjPAhVBuRQK HZfEB4EQFggpMAI\&url=https\%3A\%2F\%2Fwww.blackstonechambers.com $\%$ 2Fdocuments\%2F173\%2FPechstein_article.docx\&usg=AFQjCNH470H5PR Zw16qaDODm5H6Z0r7gTQ\&sig2=hS5ryKDeylSsyXzwMJla7w

36. Ruggie, J. G. (2016 “FOR THE GAME FOR THE WORLD.” FIFA and Human Rights. Corporate Responsibility Initiative Report No 68., Cambridge, MA: Harvard Kennedy School.

37. Zakon o potvrđivanju međunarodne konvencije protiv dopinga u sportu, NN MU 7/2007.

38. www.unesco.org, http://www.unesco.org/new/en/social-and-human-sciences/ themes/anti-doping/international-convention-against-doping-in-sport/

39. http://www.bmjv.de/SharedDocs/Zitate/DE/2015/11132015_BT_Anti-Doping. html

\section{ARBITRATION AGREEMENT IN LEGAL MATTERS RELATED TO INTERNATIONAL SPORT}

Sports arbitration, as any other arbitration, is based on the arbitration agreement. Arbitration agreement, similarity to any other agreements, to be valid, should fulfil the conditions of formal and material validity. Peculiarities of arbitration agreement are found in the special way of consent given to arbitration and the qualification of that consent will be crucial for the validity of arbitration agreement. Court of Arbitration for Sport (CAS), often called as the Supreme Court for Sports is an institution for the dispute resolution in sports whose jurisdiction is based upon that kind of specific arbitration agreement. Even though the validity of arbitration agreement is a precondition for commencement of arbitration procedures, also before CAS, it's validity could be questioned even later, in appeal before Swiss Federal Tribunal or when deciding on the recognition and enforcement of foreign arbitral awards applying the Newyork Convention 1958. Modern age reviewed the foundations of sports arbitration as a system on the global scale. The prominent case of Claudia Pechstein internationally began before CAS but had its sequence and culmination before German Courts. Sports Community intensely expected the decision of the Bundesgerichsthof (BHG) in May 2016, as it expects the decision of the European Court for Human Rights where the case is still pending. This article analyses the regulation in force as well as the jurisprudence regarding arbitration agreement, ending with the critical reviews of the decisions in the Pechstein case.

Key word: Arbitration, sport, arbitrtion agreement, CAS, pechstein case 